\title{
A Review. Fat Digestion in the Newborn: Role of Lingual Lipase and Preduodenal Digestion
}

\author{
MARGIT HAMOSH
}

Department of Physiology and Biophysics, Georgetown University Medical School, Washington, D.C., USA

\begin{abstract}
The neonatal period represents one of the most vulnerable periods in human life, particularly with respect to nutrition. During this period of rapid growth and development, there is a high demand for essential nutrients as well as for an adequate energy supply. At birth, with the sudden transfer from the high carbohydrate diet of the fetus to the high fat diet of the newborn, fat becomes the major energy source for the growing infant. In human milk and in most infant formulas, $45-50 \%$ of the total calories are present as fat, although the fat content is only $3.5-$ $4.0 \%(29,71)$. The fat content varies widely in the milk of different species, from $1.9 \%$ in the horse to 12 and $17 \%$ in the rat or reindeer,
\end{abstract} respectively; the highest amounts of fat (as much as $50 \%$ ) are found in the milk of aquatic mammals (29). More than $90 \%$ of milk fat is in the form of triglycerides (29) which contain saturated and unsaturated long-chain fatty acids esterified to glycerol (by definition long-chain fatty acids contain more than 14 carbon atoms). The overall process of fat digestion and absorption is dominated by the fact that dietary lipids, in contrast to other nutrients such as carbohydrates and protein, are nonpolar and, therefore, largely water insoluble. Digestion and absorption of dietary fat represents thus a process of transport of water-insoluble molecules from one water phase, the intestinal lumen, to another water phase, the lymph and plasma. During this process, the triglycerides are hydrolyzed to free fatty acids and 2-monoglycerides; these products of lipolysis are more polar than the triglycerides and can be solubilized within the aqueous environment of the intestine. Solubilization is achieved with the aid of bile acids through the formation of mixed micelles containing free fatty acids, monoglycerides, glycerol, and small amounts of nonpolar lipids such as diglycerides, cholesterol, and fat soluble vitamins. The products of lipolysis are taken up by the mucosal cells by passive absorption. Within the intestinal mucosa, long-chain fatty acids are bound by a special protein of low molecular weight (fatty acid binding protein) described recently by Ockner and Manning (59). After activation to acyl-CoA, the fatty acids are reesterified to form triglycerides. The newly synthesized triglycerides are assembled into chylomicrons where they form the nonpolar core of the particles, whereas polar lipids (phospholipid and cholesterol) and newly synthesized protein form the outer envelope. The chylomicrons enter the bloodstream primarily via the lymphatics. Fat digestion has been reviewed recently in several excellent articles $(6,47,58,78)$. This very short summary of the general steps involved in fat digestion and absorption outlined previously seems to stress the predominant role of the intestine in this process. Indeed, in a review on this subject, Johnston (47) stated in 1970 that "dietary triglycerides are not appreciably affected by any of the enzymatic processes involved in the gastrointestinal tract until the fat reaches the small intestine. In the duodenum, the two most important factors in the digestive process, are the intraluminal levels of pancreatic lipase (for fat hydrolysis) and of bile salts (for the solubilization of the lipids before and during lipolysis).

\section{FAT DIGESTION IN THE NEWBORN}

Whereas the absorption of dietary fat is very efficient in the adult and only as little as $4-5 \%$ of the ingested fat is excreted, this process is much less efficient in the newborn and especially in the premature infant. Fat absorption, measured either by the determination of the fat content of feces collected during 3 or more days on a standardized diet and expressed as a fraction of consumed fat $(23,79)$ or by determination of the increment in plasma triglycerides after an oral fat load (22), has been shown to be 65$75 \%$ in premature and under $85-90 \%$ in term newborns. The wide variations in the efficiency of fat absorption in the newborn depend on the type of dietary fat as well as on the functional maturity of the gastrointestinal tract at birth.

Inefficient fat absorption could be due to one or more of the following factors: impaired digestion, impaired solubilization of the products of lipolysis leading to lower uptake by the intestinal mucosa, and/or impaired reesterification within the mucosal cells.

The extensive studies of Koldovsky and his collaborators (48, 66) were among the first to point out the marked discrepancy between the high fat intake and the low activity of pancreatic and intestinal lipases in the newborn. A brief summary of their data (Table 1) shows that, whereas the fat intake is more than twice as high in 10-day-old rats, pancreatic lipase activity is only oneeighth of that in adults.

In more recent studies, Snook (74) and Deschodt-Lankman et al. (17) have shown that in the rat, pancreatic lipase activity decreases after birth and rises markedly only after weaning. Similar findings have been reported in human studies. Although zymogen granules and lipase activity have been detected in the fetal pancreas at 4-5 month of gestation (49), pancreatic lipase activity is low in newborns, especially in prematures $(16,28,57$, 83).

In addition to low pancreatic lipase activity, the newborn is unable to maintain adequate bile acid levels. In a series of elegant studies, using nonradioactive deuterium-labeled bile acid, Watkins et al. (81) have measured the total body pool of bile acid by an isotope dilution technique. Their studies, summarized in Table 2 , have shown that the bile acid pool is reduced in the newborn infant to approximately one-half of the adult values when compared on the basis of body surface area. Values for premature infants between 32-36 wk of gestation were further reduced to approximately one-half to one-third those of the full-term infants (80) (Table 2). The rate of synthesis of bile acids is lower in prematures than in term infants, who in turn have lower synthesis rates than adults (Table 2 ).

The low pancreatic lipase activity coupled with relative lack of bile acids would indicate a severe inability of the newborn to digest the high amount of dietary fat.

We have at present no information on the capacity of the jejunum of the newborn or premature infant to absorb the products of lipolysis; studies in rats have shown, however, that the absorptive capacity of fatty acids is much higher in the ileum of newborn than of adult rats (45).

In a detailed study of the mucosal phase of fat absorption, Holtzapple et al. (45) have investigated the esterifying capacity of the small intestine by evaluating the activity of microsomal enzymes as well as by measuring the capacity of whole slices to convert oleic acid to triglyceride. Their in vitro studies have shown that the uptake and rate of esterification of oleic acid by jejunal 
Table 1. Relationship between pancreatic lipase activity and fat intake in newborn and adult rats (66)

\begin{tabular}{lcc}
\hline \multicolumn{1}{c}{ Age } & Pancreatic lipase $^{1}$ & Fat intake $^{2}$ \\
\hline Suckling, 10 days old & 200 & 6.08 \\
Adult & 1700 & 2.52 \\
\hline
\end{tabular}

' U/g pancreas (wet weight).

${ }^{2} \mathrm{Cal} / 100 \mathrm{~g}$ body wt/24 hr.

Table 2. Bile salt synthesis in premature and newborn infants, cholic acid pool size and synthetic rate $(80)^{1}$

\begin{tabular}{|c|c|c|}
\hline Age & $\begin{array}{c}\text { Cholic acid pool (mg/ } \\
\left.\mathrm{m}^{2}\right)\end{array}$ & $\begin{array}{l}\text { Cholic acid synthesis (mg/ } \\
\mathrm{m}^{2} / \text { day) }\end{array}$ \\
\hline Premature $^{2}$ & $85.5 \pm 20.8$ & $34.6 \pm 6.4$ \\
\hline Full-term & $290 \pm 36$ & $110 \pm 20$ \\
\hline Adult & $600 \pm 20$ & $190 \pm 25$ \\
\hline
\end{tabular}

'Data are mean \pm SE.

${ }^{2}$ 32-36 wk gestation.

Table 3. Fatty acid absorption in the jejunum of newborn rats $(45)^{1}$

\begin{tabular}{|c|c|c|c|}
\hline Experiment & 6 Days & 11 Days & Adult \\
\hline $\begin{array}{l}\text { Fatty acid binding protein, } \\
\text { (\% of total protein) }\end{array}$ & $16.4 \pm 0.9$ & & $15.0 \pm 2.1$ \\
\hline Oleic acid binding $(\%)^{2}$ & $13.9 \pm 4.0$ & & $10.2 \pm 1.0$ \\
\hline Oleic acid uptake (nmole/g) ${ }^{3}$ & 1920 & 1216 & 448 \\
\hline $\begin{array}{l}\text { Oleic acid esterification }{ }^{3} \\
\text { (nmole/g) }\end{array}$ & 1100 & 920 & 340 \\
\hline $\begin{array}{l}\text { Oleyl-Co A synthetase } \\
\text { (nmole/mg protein/min) }\end{array}$ & $150 \pm 60$ & $150 \pm 17$ & $190 \pm 53$ \\
\hline $\begin{array}{l}\text { Acyl-Co A-monoglyceride }{ }^{4} \\
\text { acyl transferase (nmole/mg } \\
\text { protein } / \mathrm{min} \text { ) }\end{array}$ & $150 \pm 30$ & $210 \pm 66$ & $115 \pm 26$ \\
\hline
\end{tabular}

${ }^{1}$ The data are mean $\pm \mathrm{SE}$.

${ }^{2}$ Measured in the cytosol of jejunal mucosa.

${ }^{3}$ Measured in jejunal slices.

${ }^{4}$ Measured in microsomal preparations of jejunal mucosa. slices is 3-5-fold higher in suckling than in adult rats (Table 3). The activity of acyl-CoA: monoglyceride acyltransferase was 40$50 \%$ higher in microsomal preparations from suckling rats, while the activity of oleyl-CoA synthetase and the amount of fatty acid binding protein was similar in suckling and adult rats.

Because high fatty acid uptake and esterification is directly related to high levels of free fatty acids (72) and monoglycerides (53) within the intestine, it is very difficult to reconcile the marked discrepancy between low intraluminal lipolysis $(17,48,66,74)$ and increased mucosal reesterifying capacity (45) (Table 3 ). This apparent discrepancy led Henning and Kretchmer (41) to ask whether there is an alternative mechanism for fat digestion in the neonate. Indeed, our studies in rat (34) and man $(33,37)$, as well as previous studies in ruminants $(20,25-27,60,64,65,76,82)$, have shown that the digestion of dietary fat is initiated in the stomach by a potent lipase secreted from serous glands (von Ebner, 77) located at the base of the tongue. The enzyme probably plays a major role in lipid digestion in the newborn by compensating for the low activity of pancreatic lipase.

\section{INTRAGASTRIC LIPOLYSIS}

It is thought that the only role of the stomach in fat digestion is to mix the ingested fat by "churning, kneading, and squirting movements" (5) and, thereby, to help the process of emulsification.

Hydrolysis of fat in the stomach has been observed, however, by a number of investigators dating back to the end of the 19th century (for excellent reviews of the early studies, see References 14 and 48). While the early studies could not exclude contamination by pancreatic lipase as a contributing factor, later studies have definitely established the presence of lipolytic activity within the stomach (Tables 4 and 5).

The importance of the stomach in fat digestion became apparent in studies on the effect of gastrectomy on lipid absorption (52). Although the steatorrhea associated with this condition has been attributed mainly to the faster passage of food through the intestine, the facilitating action of partial fat digestion within the stomach on the further action of pancreatic lipase should not be overlooked $(20,63,67)$. The elegant studies of Borgstrom et al. (8) in 1957 have shown that considerable lipolysis (10-22\%) occurred

Table 4. Lipolytic activity in gastric contents

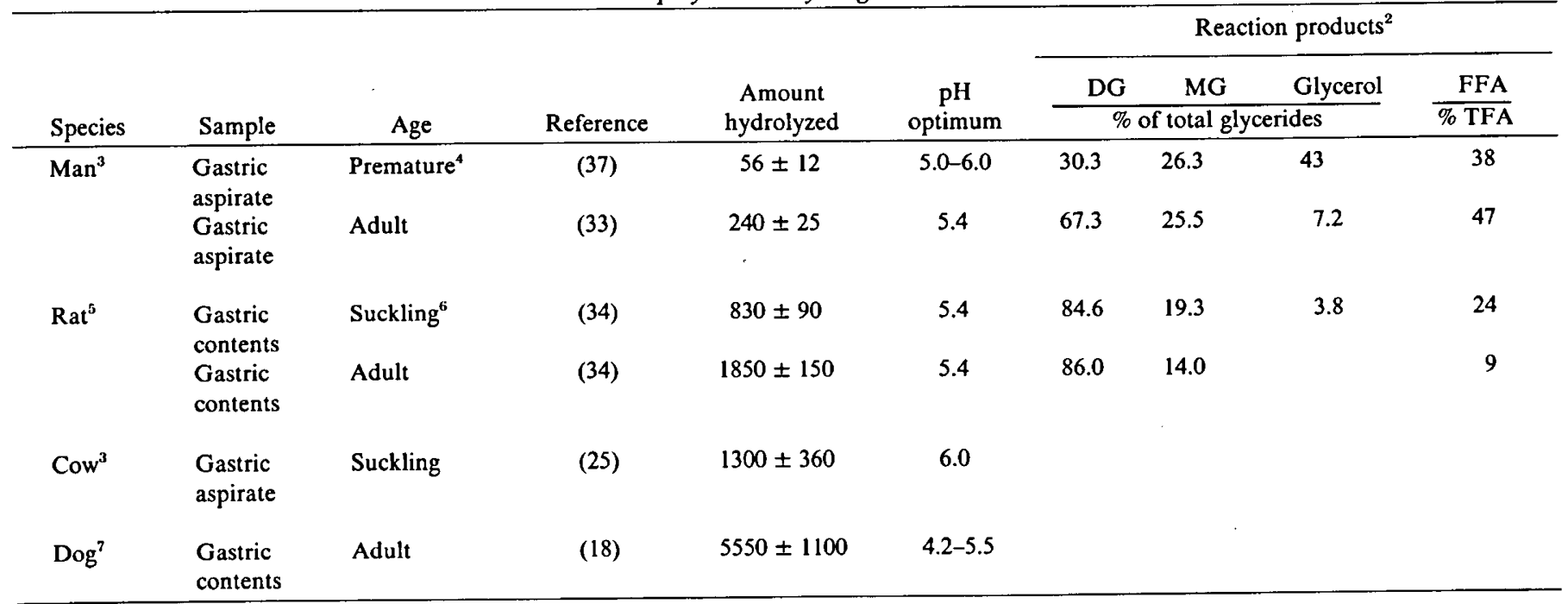

\footnotetext{
1 Data are mean $\pm S E$.

${ }^{2}$ DG, diglyceride; MG, monoglyceride; TFA, total fatty acids.

${ }^{3} \mathrm{Data}$ are $\mathrm{nmole} / \mathrm{min} / \mathrm{ml}$ aspirate.

${ }^{4}$ Premature infants, 30-34 wk of gestation.

${ }^{5}$ Data are nmole/min/g stomach contents.

63- to 6-day-old suckling rats.

${ }^{7}$ The amount of fatty acids produced was identical in normal dogs and in dogs deprived of pancreatic juice.
} 
Table 5. Intragastric digestion of dietary fat in man

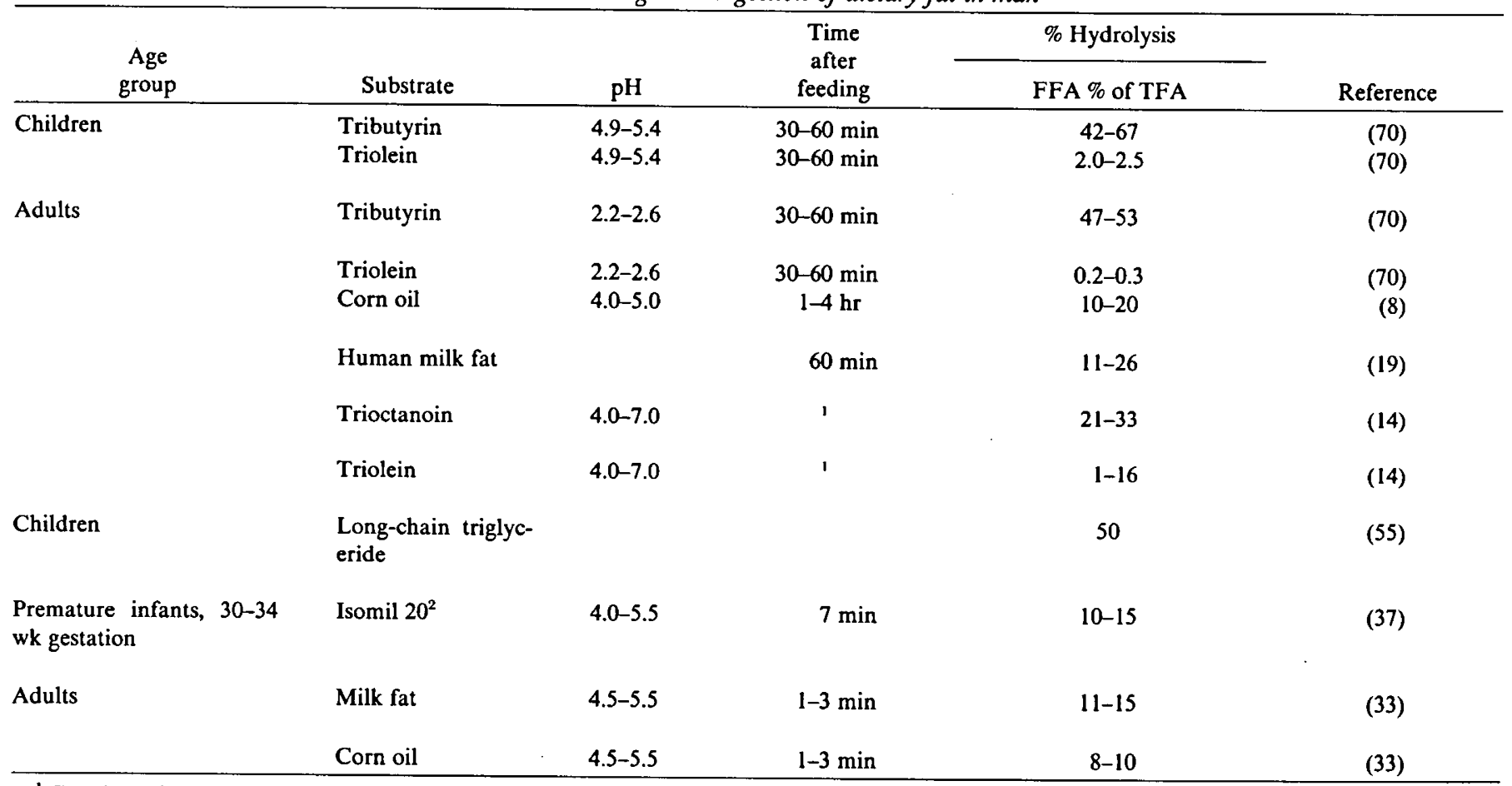

\footnotetext{
1 Gastric aspirates were incubated in vitro $60 \mathrm{~min}$.

${ }^{2}$ Isomil 20, a product of Ross Laboratories, Columbus, Ohio contains $2.1 \%$ coconut and $1.4 \%$ soy oil; both oils contain more than $80 \%$ of the lipid in the form of long-chain triglycerides.
}

in the stomach content of man (Table 5). Although the authors attributed the lipolytic activity to regurgitated intestinal contents, later studies on gastric aspirates obtained free of duodenal contamination confirmed the presence of lipase activity $(1,14,55)$ (Tables 4 and 5). Evidence of marked intragastric lipolysis is present also in other species: in the stomach of the normal dog $30 \%$ of the fat was found hydrolyzed $4 \mathrm{hr}$ after feeding (18); because the same level of lipolysis was observed after pancreatic diversion, the lipolytic enzyme was clearly of preduodenal origin (Table 4).

The lipolytic activity in gastric contents differs markedly from pancreatic lipase $(4,6,7,10)$ : the $\mathrm{pH}$ optimum is lower, in the range of $4.0-7.0(11,14,19,33,34,44,70)$, the activity is not stimulated by bile salts, which are sometimes inhibitory $(11,14$, 33 ), is higher on short and medium-chain triglycerides than on long-chain triglycerides $(11,14,70)$, and produces mainly partial glycerides and free fatty acids $(1,14,33,34)$ (Tables 4 and 5).

A gastric lipase, demonstrated by histochemical techniques within the mucosa (3) and by lipase assay in whole homogenates of the stomach wall (11), was thought to be the source of the activity in gastric contents. However, the fact that the lipase in gastric mucosa was specific for short-chain triglycerides and had almost no activity on long-chain triglycerides $(3,11)$, contrasts sharply with the marked hydrolysis of corn oil within the stomach $(8,33,34)$ and with the breakdown of triolein in samples of gastric juice free of pancreatic contamination (14) (Tables 4 and 5). Because diversion of oral secretions from the stomach by means of esophageal fistula completely abolished intragastric lipolysis in the rat (34) we have proposed that hydrolysis of dietary fat in the stomach is catalyzed by a lipase secreted from lingual serous glands (77). This assumption is based on the following additional findings: more than $95 \%$ of the total lipolytic activity within the oral cavity of the rat was present in lingual serous glands (34), whereas no lipolytic activity was found in the major salivary glands in rat (34) or man (33); the lipolytic activity present in gastric and esophageal aspirates had characteristics similar to those of lingual lipase: low $\mathrm{pH}$ optimum (5.0-5.5), activity on long-chain triglycerides, and production of mainly partial glycerides and free fatty acids $(31,33,34,37,69)$ (Table 6). Several of these characteristics such as maximal activity in the absence of bile salts $(31,33,37)$ and sharp rise in enzyme activity immediately after birth (32) (Table 7) indicate that the enzyme might be ideally suited for activity in the newborn. The reaction products, monoglycerides and free fatty acids, are amphiphilic substances that stabilize lipid emulsions (73), and could, thus, help to overcome the partial lack of bile salts in the newborn.

\section{ORIGIN OF ENZYME ACTIVITY}

Lingual lipase is present in lingual serous glands (von Ebner, 77), a group of tubuloalveolar glands located beneath the single large circumvallate papilla of the rat (2l), or the entire region of the circumvallate papillae (2-9) in man (5). The papillae are found on the proximal dorsal surface of the tongue; the glands are embedded in the underlying muscular tissue and their ducts open at the base of the papillae. Von Ebner's glands have been described in a large number of mammals (15). The fine structure of the glands, studied in the rat (38) and man (31), is similar to that of other exocrine glands $(49,75)$. The acinar cells are packed with numerous electron-dense, membrane bounded secretory granules that range in size from $400-1700 \mathrm{~nm}$ in diameter in the glands of man (31) or rat (38). Lipase activity is contained within the secretory granules (30), and is rapidly released after feeding, and sympathetic or parasympathetic stimulation (30). In ruminants, lipase activity was also present in extracts of glandular tissue from the back and root of the tongue and from the pharyngeal end of the esophagus (64).

Whether there is any connection between taste buds, present in the walls of the circumvallate papillae (5) and the activity of the lingual serous glands, where ducts open into the trough of the papillae $(38,54)$, is not known at present. A similar proximity of taste buds (54) and lipase (34) containing serous glands exists also in the soft palate (50). In addition, the appearance of taste buds (54) and of lipase activity (32) occurs at the same time in the fetal rat. It has originally been proposed that the function of the serous secretion of von Ebner's gland is to wash out the taste buds "in order to prepare them for new stimuli" (5). Furthermore, Baradi 
Table 6. Hydrolysis of long-chain triglyceride by lingual (oro-pharyngeal) lipase: characteristics of the lipolytic activity

\begin{tabular}{|c|c|c|c|c|c|c|c|c|c|}
\hline \multirow[b]{3}{*}{ Species } & \multirow[b]{3}{*}{ Source } & \multirow[b]{3}{*}{ Age } & \multirow[b]{3}{*}{ Reference } & \multirow{3}{*}{$\begin{array}{c}\text { Amount } \\
\text { hydrolyzed }\end{array}$} & \multirow{3}{*}{$\begin{array}{c}\mathrm{pH} \\
\text { optimum }\end{array}$} & \multicolumn{4}{|c|}{ Reaction products ${ }^{2}$} \\
\hline & & & & & & DG & MG & Glycerol & FFA \\
\hline & & & & & & \multicolumn{3}{|c|}{$\%$ of total glycerides } & $\overline{\% \text { TFA }}$ \\
\hline \multirow[t]{3}{*}{ Man } & $\begin{array}{l}\text { Esophageal } \\
\text { aspirate }^{3}\end{array}$ & Newborn ${ }^{4}$ & (69) & $13.24 \pm 10.6$ & 5.4 & 26.25 & 28.4 & 45 & 36 \\
\hline & $\begin{array}{l}\text { Esophageal } \\
\text { aspirate }^{3}\end{array}$ & Adult & (33) & $53.5 \pm 10.3$ & 5.4 & 75.9 & 21.0 & 3.1 & 43 \\
\hline & Tongue $^{5}$ & Adult $^{6}$ & (31) & $0.30 \pm 0.08$ & $4.5-5.5$ & 58.0 & 7.0 & 31.6 & 44 \\
\hline \multirow{2}{*}{ Rat } & Tongue $^{5}$ & Newborn $^{7}$ & (34) & $15.0 \pm 1.2$ & $4.5-5.5$ & 70.0 & 18.6 & 11.6 & 20 \\
\hline & Tongue $^{5}$ & Adult & (34) & $66.4 \pm 6.0$ & $5.0-5.5$ & 69.0 & 25.6 & 5.2 & 25 \\
\hline Cow & $\begin{array}{l}\text { Esophageal } \\
\text { aspirate }\end{array}$ & Newborn $^{8}$ & $(25)$ & $35.6 \pm 6.6$ & $4.5-6.0$ & 67.6 & 32.4 & & 18 \\
\hline
\end{tabular}

'Data are mean $\pm \mathrm{SE}$.

${ }^{2}$ DG, diglyceride; MG, monoglyceride; TFA, total fatty acids.

${ }^{3}$ Data are $\mathrm{nmole} / \mathrm{min} / \mathrm{ml}$ aspirate.

4 Aspirates from the esophageal pouch were obtained from three infants with congenital esophageal atresia.

${ }^{5}$ Data are nmole/min/mg tissue.

${ }^{6}$ Tongue homogenate of post mortem specimens of glandular tissue from the region of the vallate papillae.

7.3- to 6-day-old suckling rats.

${ }^{8}$ The aspirate was obtained via esophageal fistula in 2 - to 3 -wk-old calves; data are $\mu \mathrm{mole} / \mathrm{min} / \mathrm{ml}$. Substrate tributyrin.

\section{Table 7. Characteristics of lingual lipase}

1. Secreted from lingual serous glands (von Ebner); absent from secretions of major salivary glands (parotid, sublingual, mandibular).

2. Site of action: stomach.

3. $\mathrm{pH}$ optimum 4.5-5.5.

4. Substrate long-chain triglyceride.'

5. Reaction products: diglyceride, monoglyceride, FFA, glycerol.

6. Bile salts not needed for activity.

7. Enzyme activity high in newborns.

8. Sucking and high fat diet stimulate enzyme activity.

\footnotetext{
'In rat and human preparations $(31,34)$; in the ruminant activity is highest on short-chain triglyceride $(27,64)$.
}

and Bourne (2) have suggested that the secretion could be of importance to the sense of taste. Lipase activity is completely absent from the major salivary glands of all species studied (27, 34) including man (33).

\section{LINGUAL SEROUS GLANDS DURING DEVELOPMENT}

The structural development of the serous glands of the tongue and of lingual lipase have recently been investigated in the rat (32). The lingual serous glands were initiated in 19- to 20-day fetuses as epithelial ingrowths from the vallate and foliate papillae (gestation in the rat is 22 days). Lipase activity was first detected in 20-day-old fetuses and increased 14-fold by birth. The only serous cells containing appreciable numbers of secretory granules and exhibiting signs of exocytosis were the demilune cells of the lingual mucous glands (Fig. 1). The data suggest that lipase activity detectable in the tongues of 20-day-old fetuses originates predominantly in the demilune cells of the mucous glands. During the first suckling period, lipase activity decreased by $50 \%$, presumably due to the release of stored enzyme, because no decrease in enzyme activity was noted in animals removed from the mother immediately after birth. By the second postnatal day, the activity had returned to birth levels and continued to rise exponentially thereafter.

Beginning at 3-4 days postnatally, synthesis and storage of enzyme by the differentiating lingual serous glands probably contributes to the rapid rise in lipase levels. The developmental pattern of lingual lipase thus differs markedly from that of pancreatic lipase. Although both enzymes are present in the fetus $(9$, $32,49,69)$, pancreatic lipase activity decreases sharply after birth and remains low until weaning $(16,17,74)$, whereas lingual lipase activity rises rapidly after birth (32), reaching adult activity levels at 17 days (before weaning).

The secretion of a potent lipase in the proximal part of the oral cavity raised the question whether aspiration of saliva (a frequent occurence in the newborn) could lead to breakdown of lung surfactant, a complex phospholipid that lines the alveoli and is essential for normal lung function (12). Because lecithin is the major component of surfactant (12), we have tested whether it is a substrate for lingual lipase. The complete lack of activity on lecithin (Hamosh et al,, unpublished observations) agrees well with the studies of Paltauf et al. (61), who showed that lingual lipase attacks the $\mathrm{Sn}-3$ position of triglycerides twice as fast as the $\mathrm{Sn}-1$ position. The presence of the phosphoryl-choline group at the $\mathrm{Sn}-3$ position probably completely prevents enzyme activity.

\section{INTRAGASTRIC DIGESTION IN SUCKLING RUMINANTS}

The most thorough studies of intragastric digestion of dietary fat have been conducted in ruminants. These studies have been addressed to the origin of the lipolytic enzyme $(60,64,65,76)$, the regulation of enzyme secretion by factors such as suckling $(27,51$, 64,82 ) and amount of fat in the diet $(27)$, as well as the possible facilitating action of partial digestion by lingual lipase on further lipolysis by pancreatic lipase (20). In earlier studies, Ramsey and Young (65) and Otterby et al. (60) have compared the extent of lipolysis of whole-milk diets given orally or introduced directly into the abomasum (the equivalent of the stomach in nonruminants) and have concluded that a salivary lipase, which they called pregastric esterase was primarily responsible for the hydrolysis of milk fat. The techniques used in these studies did not, however, rule out the possibility that part of the lipolytic activity originated in secretions of the abomasal mucosa or from pancreatic lipase in regurgitated duodenal contents. Definite proof that the lipolytic activity originates in the oral cavity comes from recent studies of Toothill et al. (76) who found no lipolytic activity in secretions obtained from innervated pouches of the abomasum. Because in ruminants the only tissues containing lipase activity are those in and around the base of the tongue (64), one may conclude that they are the source of the lipase active in the abomasum of the preruminant calf.

The high lipolytic activity in suckling calves is probably a temporary adaptation to the high fat content of milk. Ruminants normally consume low fat diets and are not particularly well 


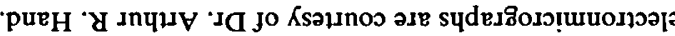

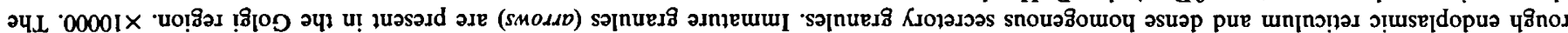

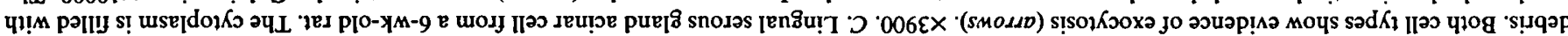

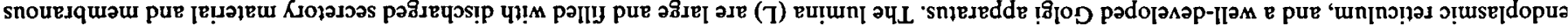

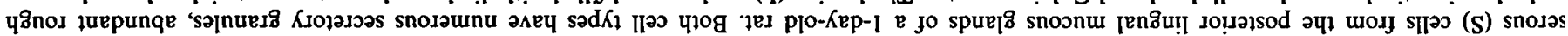

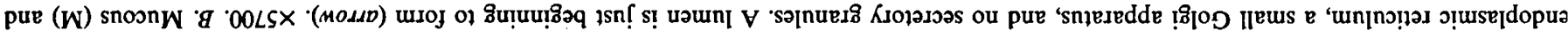

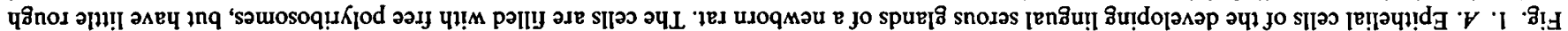
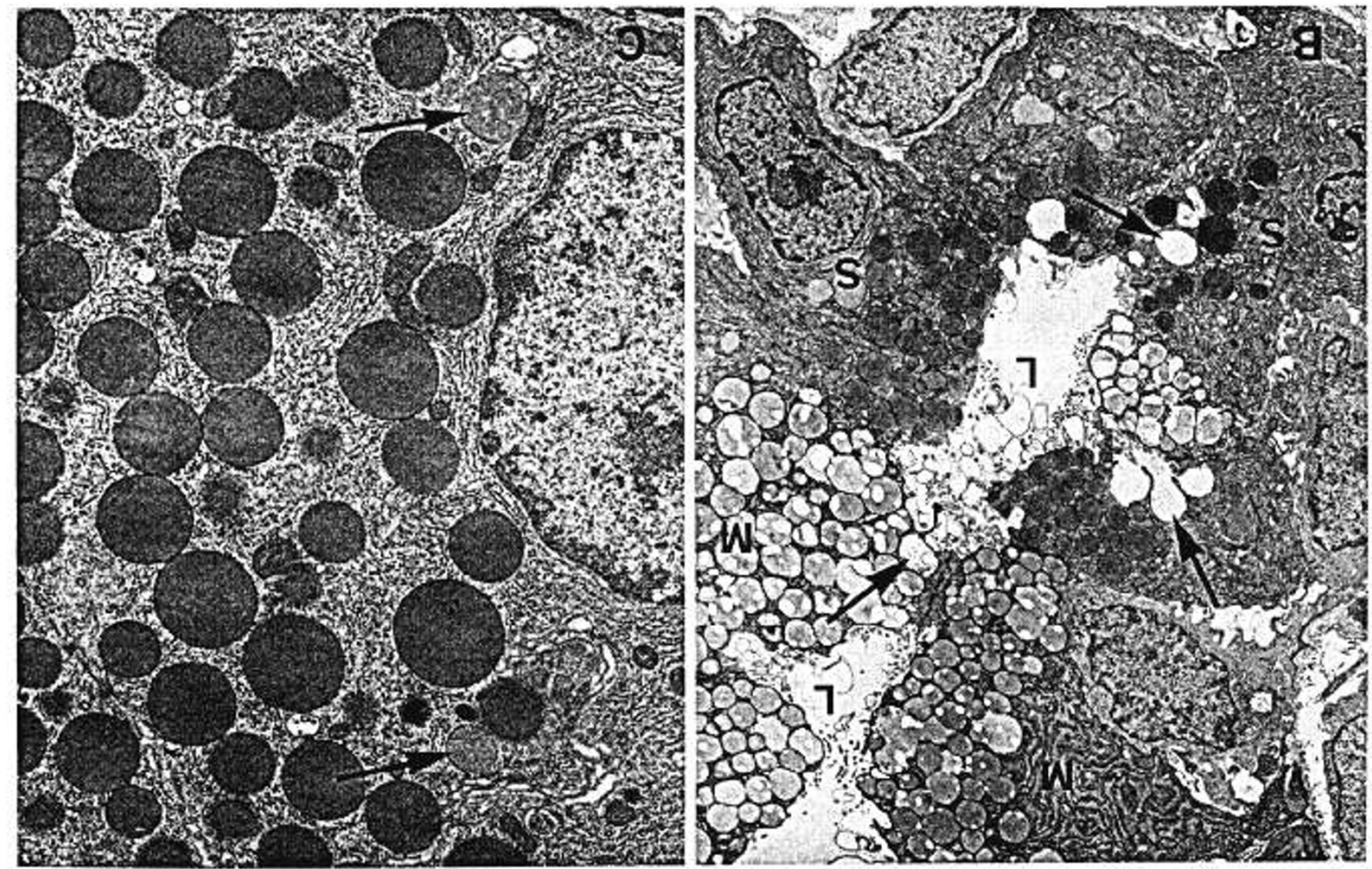

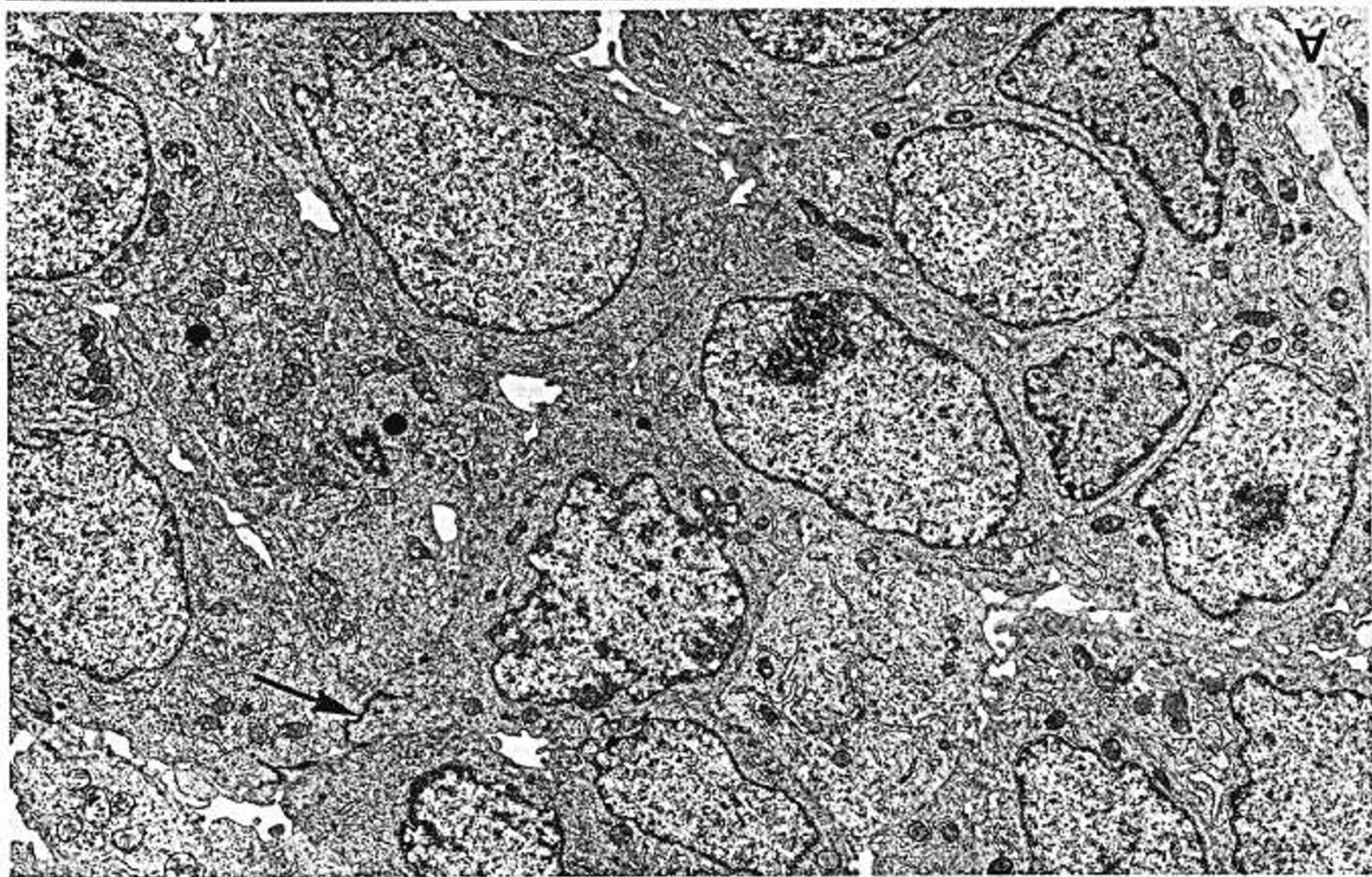


Table 8. Lipid digestion in the absence of pancreatic lipase in calves $^{1,2}(26)$

\begin{tabular}{ccccc}
\hline & \multicolumn{4}{c}{ Lipid fractions in jejunal contents of milk-fed calves (\% of total lipids) } \\
\cline { 2 - 5 } Pancreatic juice & Triglyceride & Diglyceride & Monoglyceride & Free fatty acids \\
\hline Absent & $53.0 \pm 1.7$ & $15.4 \pm 0.7$ & $12.8 \pm 0.5$ & $18.8 \pm 0.7$ \\
Present & $39.8 \pm 1.6$ & $18.4 \pm 0.9$ & $14.2 \pm 1.2$ & $27.6 \pm 1.1$ \\
\hline
\end{tabular}

\footnotetext{
'The data are mean $\pm S E$.

${ }^{2}$ Lipid digestion was studied in four calves fitted with a shunt between the pancreatic duct and duodenum and an additional cannula in the upper jejunum approximately $1 \mathrm{~m}$ distal to the entrance of the pancreatic duct.
}

Table 9. Lipid absorption in the absence of pancreatic lipase in calves $^{1,2}(26)$

\begin{tabular}{lcc}
\hline \multirow{2}{*}{} & \multicolumn{2}{c}{ Pancreatic juice } \\
\cline { 2 - 3 } & Absent & Present \\
\hline Long-chain TG-FA ${ }^{3}$ fed (g) & $66.8 \pm 3.8$ & $72.4 \pm 5.9$ \\
Dietary long-chain fatty acid absorbed & $46.0 \pm 2.1$ & $69.9 \pm 6.3$ \\
(g) & $69.1 \pm 3.3$ & $96.5 \pm 3.1$ \\
\hline
\end{tabular}

' Data are mean $\pm S E$.

${ }^{2}$ The quantity of lipid absorbed into lymph during normal flow of pancreatic juice and during pancreatic deprivation was studied in six calves with shunts established between the thoracic duct and the left common jugular vein as well as between the pancreatic duct and the duodenum.

${ }^{3}$ Triglyceride - fatty acid.

adapted to digest fat. In addition, continuous suckling is probably an important stimulus for high enzyme activity. Lipolytic activity in oral tissues (64) and in salivary secretions, collected either via an esophageal fistula or directly from the mouth $(27,65)$, was higher in young calves and declined sharply as the animals became older. Moreover, feeding of milk via a nipple maintained high lipase activity in 4-yr-old steers (51). The importance of intragastric lipolysis to the overall digestion and absorption of dietary fat in the preruminant calf is stressed by the careful studies of Gooden and Lascelles (26) who found that after the diversion of pancreatic secretions, $47 \%$ of milk fat entered the ileum digested to partial glycerides and free fatty acids, compared to $60 \%$ in intact calves (Table 8). Furthermore, $70 \%$ of long-chain triglyceride-fatty acids were absorbed in the absence of pancreatic juice (Table 9). The very efficient digestion and absorption of dietary fat $(96.5 \%)$ in normal calves is probably the result of the combined action of lingual and pancreatic lipase. Recent in vitro studies have shown that the release of fatty acids by pancreatic lipase was enhanced by preincubation of milk fat with salivary lipase (20). The combined action of the two lipases may be of considerable importance to the very young calf, because the level of pancreatic lipase activity is low at this age (46).

\section{FAT DIGESTION IN THE NEWBORN}

Considerable hydrolysis of milk triglyceride to partial glycerides and free fatty acids occurs in the stomach of suckling rats $(36,40)$ and of newborn premature and term infants $(37,69)$ (Table 5). Information on the mechanism of fat digestion in the stomach of the newborn is based mainly on studies in rats. In young (3- to 10days-old), fed rats, the stomach is distended by a milk clot that is solid in the fundic region and semisolid in the anthral part of the stomach (62). The pH within this milk clot is usually 5-6, dropping in the pyloric region to $3.5-4.5(34,39)$. This suggests that there is very little peptic activity (pH optimum $2-3$ ) within the milk clot. One may assume, therefore, that lingual lipase, mixed with the ingested milk before swallowing, has optimal lipolytic conditions within the stomach. Sucking probably facilitates enzyme secretion from lingual serous glands. The intermittent changes in pressure (negative during suck and positive during swallow) probably enhance the emptying of the serous secretion, whereas bolus accumulation in this area facilitates mixing of milk and enzyme. Initial digestion by lingual lipase could markedly enhance the hydrolysis of milk fat because milk fat droplets are not a good substrate for human pancreatic lipase (14). Indeed, our recent studies have shown that after exclusion of lingual lipase, there is marked reduction of intragastric hydrolysis of milk fat in rats, leading in turn to lower lipolysis in the duodenum and jejunum (63). In addition, our initial assumption that partial hydrolysis within the stomach is essential to proper emulsification of dietary fat (33) has recently been confirmed by Roy et al. (67) who showed that fat absorption dropped from $88.5 \pm 7.5 \%$ in normal to 59.7 $\pm 7 \%$ in rats with esophageal fistula. The difference between the two groups was almost abolished when the fat meal was presented as a fine emulsion.

A recent study confirms the importance of intragastric lipolysis in fat digestion of premature infants (68). A comparison of fat absorption in two groups of infants of $30 \mathrm{wk}$ gestational age showed much lower fat excretion (14.9 $\pm 1.7 \%$ of ingested fat) in nasogastric fed infants than in a nasojejunal fed group (23.0 \pm $2.9 \%$ ingested fat). Very high intragastric lipolysis and absorption of more than $50 \%$ of dietary fat have recently been described in a case of congenital pancreatic lipase deficiency (55). The observations suggest that in the absence of pancreatic lipase, intragastric lipolysis can compensate efficiently in the digestion and absorption of dietary fat.

The presence of lipase activity in esophageal pouches of infants with congential esophageal atresia indicates that enzyme activity in infants as in adults probably originates in the lingual serous glands; lipase activity in gastric aspirates of these children indicates, however, that lipolytic activity probably originates, concomitantly also within the stomach (69). Whether fat digestion in the newborn could, in addition, be aided by lipases in the intestinal mucosa or in milk is unknown at present. The intestinal mucosa contains several lipases $(13,56)$ among them an "acid lipase" that is substantially higher in suckling than in adult rats (13); however, the physiologic significance of these enzymes has not been defined. Although milk contains two lipases, lipoprotein lipase $(35,43)$ and bile salt-stimulated lipase $(24,42)$, it is doubtful that the former participates in the digestive process because it is inactive in the absence of serum proteins, whereas the role of the latter remains to be tested:

\section{REFERENCES AND NOTES}

1. Bank, S. L., Krut, L. H., Marks, N., Bronly-Stewart, B., and Le R Uys, P. J.: Hydrolysis of fat by human gastric juice. Gut, S: 480 (1964).

2. Baradi, A. F., and Bourne, G. H.: Gustatory and olfactory epithelia. Intern. Rev. Cytol., 2: 289 (1953).

3. Barrowman, J. A., and Darnton, S. J.: The lipase of rat gastric mucosa. A histochemical demonstration of the enzymatic activity against a medium chain triglyceride. Gastroenterology, 59: 214 (1969).

4. Benzonana, G., and Desnuelle, P.: Etude cinetique de l'action de la lipase pancreatique sur des triglycerides en emulsion: essai d'une enzymologie en milieu heterogene. Biochim. Biophys. Acta, 105: 121 (1965).

5. Bloom, W. and Fawcett, D. W.: In: A Textbook of Histology. Ed. 8, Chap. 21, p. 405, (W. B. Saunders Company, Philadelphia, 1962).

6. Borgström, B.: Digestion and absorption of lipids. In: R. K. Crane: International Review of Physiology, Vol. 12. Gastrointestinal Physiology II, p. 305 (Univer- 
sity Press, Baltimore, 1977).

7. Borgström, B.: On the interactions between pancreatic lipase and colipase and the substrate and the importance of bile salts. J. Lipid Res., 16: 411 (1975).

8. Borgström, B., Dahlqvist, A., Lundh, G., and Sjovall, J.: Studies of intestinal digestion and absorption in the human. J. Clin. Invest., 36: 1521 (1957).

9. Bradshaw, W. S., and Rutter, W. J.: Multiple pancreatic lipases. Tissue distribution and pattern of accumulation during embriological development. Biochemistry, 11: 1517 (1972).

10. Brockerhoff, H., and Jensen, R. G.: In: Lipolytic Enzymes, p. 330 (Academic Press, New York, 1974).

11. Clark, B. S., Brause, B., and Holt, P. R.: Lipolysis and absorption of fat in the rat stomach. Gastroenterology, 56: 214 (1969).

12. Clements, J. A.: In: C. A. Villee, D. B. Villee, and J. Zuckerman: Composition and Properties of Pulmonary Surfactant in Respiratory Distress Syndrome, p. 205 (Academic Press, New York, 1973).

13. Coates, P. M., Brown, S. A., Jumavan, J., and Koldovsky, O.: Characteristics and postnatal development of the acid lipase activity of the rat's small intestine. Biochem. J., 166: 331 (1977).

14. Cohen, M., Morgan, G. R. H., and Hofmann, A. F.: Lipolytic activity of human gastric and duodenal juice against medium and long chain triglycerides. Gastroenterology, 60: 1 (1971).

15. De Barros, J.: Histochemical study of the von Ebner acinar glands and the Weber gland located at the posterior region of the tongue of some mammals. Arq Cent. Estud. Fac. Odontol. (Brazil, Fed. Univ. Espirito Santo) 10, \#1-2, 1973.

16. Delachaume-Salem, E., and Sarles, H.: Evolution en fonction de l'age de la secretion pancreatique humaine normale. Biol. Gastroenterol. (Paris), 2: 135 (1970).

17. Deschodt-Lanckman, M., Robbercht, P., Camus, J., Baya, C., and Christophe, J.: Hormonal and dietary adaptation of rat pancreatic hydrolases before and after weaning. Am. J. Physiol., 226: 39 (1974).

18. Douglas, G. J. Jr., Reinauer, A. J., Brooks, W. C., and Pratt, J. H.: The effect on digestion and absorption of excluding the pancreatic juice from the intestine. Gastroenterology, 23: 452 (1953).

19. Eastwood, M. A., and Hamilton, D.: Fatty acids in the lumen of the small intestine in man following a lipid containing meal. Scand. J. Gastroenterol. 5: 225 (1970).

20. Edwards-Webb, J. D., and Thompson, S. Y.: Studies on lipid digestion in the preruminant calf. A comparison of the products of lipolysis of milk fat by salivary and pancreatic lipases in vitro. Br. J. Nutr., 37: 431 (1977).

21. Ellis, R. A.: Circulatory patterns in the papillae of the mammalian tongue. Anat. Rec., 133: 579 (1959).

22. Fallstrom, S. P., Nygren, C. O., and Olegard, R.: Plasma triglyceride increase after oral fat load in malabsorption during early childhood. Acta Prediatr. Scand., 66: 111 (1977)

23. Fomon, S. J., Ziegler, E. E., Thomas, L. M., Jensen, R. L., and Filer, L. J. Excretion of fat by normal full-term infants fed various milks and formulas. Am. J. Clin. Nutr., 28: 1299 (1970)

24. Freudenberg, E.: Die Frauenmilch-Lipase. (Karger, Basel, 1953).

25. Gooden, J. M.: The importance of lipolytic enzymes in milk fed and ruminating calves. Aust. J. Biol. Sci., 26: 1189 (1973).

26. Gooden, J. M., and Lascelles, A. K.: Relative importance of pancreatic lipase and pregastric esterase in lipid absorption in calves 1-2 weeks of age. Aust. J. Biol. Sci., 26: 625 (1973).

27. Grosskopf, J. F. W.: Study on salivary lipase in young ruminants. Onderstepoort, J. Vet. Res., 32: 153 (1965)

28. Gschwind, von Ruth: Das verhalten der Pankreasenzyme bei Frugheburten. Ann. Pediatr., 175: 176 (1950).

29. Hambraeus, L.: Proprietory milk versus human breast milk in infant feeding Pediatr. Clin. N. Am., 24: 17 (1977).

30. Hamosh, M.: Rat lingual lipase: I. Factors affecting enzyme activity and secretion. Am. J. Physiol. 235: E416 (1978).

31. Hamosh, M., and Burns, W. A.: Lipolytic activity of human lingual glands (Ebner). Lab. Invest., 37: 603 (1977).

32. Hamosh, M., and Hand, A. R.: Development of secretory activity in serous cells of the rat tongue. Develop. Biol., 65: 100 (1978).

33. Hamosh, M., Klaeveman, H. L., Wolf, R. O., and Scow, R. O.: Pharyngeal lipase and digestion of dietary triglyceride in man. J. Clin. Invest., 55: 908 (1975).

34. Hamosh, M., and Scow, R. O.: Lingual lipase and its role in the digestion of dietary fat. J. Clin. Invest., 52: 88 (1973).

35. Hamosh, M., and Scow, R. O.: Lipoprotein lipase activity in guinea pig and rat milk. Biochim. Biophys. Acta, 231: 283 (1971).

36. Hamosh, M., and Scow, R. O.: In: Nutrition: Plasma triglyceride and lipoprotein lipase activity in pregnant and lactating rats, p. 207 (Excerpta Medica Foundation, Amsterdam, International Congress Series no. 213, 1970).

37. Hamosh, M., Sivasubramanian, K. N., Salzman-Mann, C., and Hamosh, P.: Fat digestion in the stomach of premature infants. J. Pediatr. 93: 674 (1978).

38. Hand, A. R.: The fine structure of von Ebner's gland of the rat. J. Cell Biol., 44: 340 (1970).

39. Helander, H. F.: Gastric acidity in young and adult mice. Scand. J. Gastroenterol., 5: 221 (1970).

40. Helander, H. F., and Olivercrona, T.: Lipolysis and lipid absorption in the stomach of the suckling rat. Gastroenterology, 59: 22 (1970).

41. Henning, S. J.; and Kretchmer, N.: Development of intestinal function in mammals. Enzyme, 15: 3 (1973).

42. Hernell, O.: Human milk lipases. III. Physiological implications of the bile salt stimulated lipase. Eur. J. Clin. Invest., 2: 267 (1975).
43. Hernell, O., and Olivercrona, T.: Human milk lipases. I. Serum-stimulated lipase. J. Lipid Res., 15: 367 (1974).

44. Herting, D. C., and Ames, S. R.: On the gastric lipolysis of fat. Arch. Biochem. 55: 295 (1955).

45. Holtzapple, P. G., Smith, G., and Koldovsky, O.: Uptake, activation, and esterification of fatty acids in the small intestine of the suckling rat. Pediatr. Res., 9: 786 (1975).

46. Huber, J. T., Jacobson, N. L., Allen, R. S., and Hartman, P. A.: Digestive enzyme activities in the young calf. J. Dairy Sci., 44: 1494 (1961).

47. Johnston, J. M.: Intestinal absorption of dietary fat. Compr. Biochem., 18: 1 (1970).

48. Koldovsky, O.: In: Development of the Function of the Small Intestine in Mammals and Man. (Karger, Basel, 1969).

49. Laitio, M., Lev, R., and Orlic, D.: The developing human fetal pancreas: an ultrastructural and histochemical study with special reference to exocrine cells. J. Anat., 117: 619 (1974).

50. Leeson, C. R., and Leeson, T. S.: Fine structure and possible secretory mechanism of rat palatine glands. J. Dent. Res., 47: 653 (1968).

51. Leidy, R. B., Russell, R. W., and Wise, G. H.: Pregastric esterase in milk sham fed to adult jersey steers. J. Dairy Sci., 58: 563 (1975).

52. Lundh, G.: Intestinal digestion and absorption after gastrectomy. Acta Clin. Scand. Suppl. 231: 4 (1958).

53. Marrubio, A. T. Jr., Morris, J. A. Jr., Clark, S. B., and Holt, P. R.: Monoglyceride modification of jejunal absorption of fatty acid in the rat. J. Lipid Res., 15: 165 (1974).

54. Mistretta, C. M.: Topographical and histological study of the developing rat tongue, palate and taste buds. In: J. F. Bosma: The Third Symposium on Oral Sensation and Perception: The Mouth of the Infant, p. 163 (Charles C Thomas, Springfield, 1972).

55. Muller, D. P. R., Mc.Collum, J. P. K., Trompeter, R. S., and Harries, J. T.: Studies on the mechanism of fat absorption in congenital isolated lipase deficiency. Gut, 16: 838 (1975).

56. Negrel, R., Serrero, G., Fernandez-Lopez, V., and Ailhaud, G.: Esterolytic activity of rat intestinal mucosa. Eur. J. Biochem., 71: 249 (1976).

57. Norman, A., Strandvik, B., and Ojamae, O.: Bile acids and pancreatic enzymes during absorption in the newborn. Acta Pediatr. Scand., 61: 571 (1972).

58. Ockner, R. K., and Isselbacher, K. H.: Recent concepts of intestinal fat absorption. Rev. Physiol. Biochem. Pharmacol., 71: 107 (1974).

59. Ockner, R. N., and Manning, J. A.: Fatty acid binding protein in small intestine. Identification, isolation and evidence for its role in cellular fatty acid transport. J. Clin. Invest., 54: 326 (1974).

60. Otterby, D. E., Ramsey, H. A., and Wise, G. H.: Lipolysis of milk fat by pregastric esterase in the abomasum of the calf. J. Dairy Sci., 47: 993 (1964).

61. Paltauf, F., Esfandi, F., and Holasek, A.: Stereospecificity of lipases. Enzymic hydrolysis of enantiomeric alkyl diacylglycerols by lipoprotein lipase, lingual lipase and pancreatic lipase. FEBS. Lett. 40: 119 (1974).

62. Platt, B. S.: Digestion in infancy. Fed. Proc. Suppl., 7: 188 (1961).

63. Plucinski, T., Hamosh, M., and Hamosh, P.: Lipid digestion in the rat: effect of gastric lipolysis on the intestinal hydrolysis of dietary fat. Fed. Proc., 37: 700 (1978).

64. Ramsey, H. A., Wise, G. H., and Tove, S. B.: Esterolytic activity of certain alimentary tissues from cattle in different age groups. J. Dairy Sci., 39: 1312 (1956).

65. Ramsey, H. A., and Young, J. W.: Role of pregastric esterase in the abomasal hydrolysis of milk fat in the young calf. J. Dairy Sci., 44: 2227 (1961).

66. Rokos, J., Hahn, P., Koldovsky, O., and Prochazka, P.: The postnatal development of lipolytic activity in the pancreas and small intestine of the rat. Physiol. Bohemoslov., 12: 213 (1963).

67. Roy, C. C., Lefebre, D., and Chartrand, L.: The role of gastric lipolysis in fat absorption and bile acid metabolism in the rat. Clin. Res., 25: 689A (1977).

68. Roy, R. N., Pollinitz, R. P., Hamilton, J. R., and Chance, G. W. Impaired assimilation of nasojejunal feeds in healthy low-birth-weight newborn infants. J. Pediatr., 90: 431 (1977).

69. Salzman-Mann, C., Hamosh, M., Sivasubramanian, K. N., Avery, G. B., Plucinski, T., Watkins, J. B., and Hamosh, P.: Lipolytic activity in esophageal and gastric aspirates from infants with esophageal atresia. Fed. Proc., 37: 854 (1978).

70. Schonheyder, F., and Volquartz, K.: The gastric lipase in man. Acta Physiol. Scand., 11: 349 (1946).

71. Silverman, A., Roy, C., and Cozetti, F. H.: In: Clinical pediatric gastroenterology, p. 512 (The C. V. Mosby Company, St. Louis, 1971).

72. Singh, A., Baliant, J. H., Edmonds, R. H., and Rodgers, J. B.: Adaptive changes of the rat small intestine in response to a high fat diet. Biochim. Biophys. Acta, 260: 708 (1972).

73. Small, D. M.: A classification of biologic lipids based upon their interaction in aqueous systems. J. Am. Oil. Chem. Soc., 45: 108 (1968).

74. Snook, J. T.: Effect of diet on development of exocrine pancreas of the neonatal rat. Am. J. Physiol., 221: 1388 (1971).

75. Tandler, B., and Erlandson, R. A.: Ultrastructure of the human submaxillary gland: serous granules. Am. J. Anat., 135: 419 (1972).

76. Toothill, J., Thomson, S. Y., and Edwards-Webb, J. D.: Studies on lipid digestion in the preruminant calf. The source of lipolytic activity in the abomasum. Br. J. Nutr., 36: 439 (1976).

77. Von Ebner, V.: Cited in V Koelliker's Handb D Geweblehre d Menschen. Vol. 3, p. 18, Die acinosen Drusen der Zunge und ihre Beziehungen zu den Geschmacksorganen. (Leuschner und Lubensky, Graz, Austria, 1899). 
78. Watkins, J. B.: Mechanism of fat absorption and the development of gastrointestinal function. Pediatr. Clin. N. Am., 22: 721 (1975).

79. Watkins, J. B., Bliss, C. M., Donaldson, R. M. Jr., and Lester, R.: Characterization of newborn fecal lipid. Pediatrics, 53: 511 (1974).

80. Watkins, J. B., Szezcepanik, P., Gould, J. B., Klein, P. D., and Lester, R.: Bile salt kinetics in premature infants. An explanation for inefficient lipid absorption. Gastroenterology, 69: 706 (1975).

81. Watkins, J. B., Szczepanik, P., Ingall, D., Klein, P. D., and Lester, R.: Bile salt metabolism in the newborn infant. Measurement of pool size and synthesis by stable isoptopic technique. N. Engl. J. Med., 288: 431 (1973).

82. Young, J. W., Ramsey, H. A., and Wise, G. H. Effects of age and diet on the secretion of pregastric esterase in calves. J. Dairy Sci., 43: 1068 (1960).

83. Zoppi, G., Andreotti, G., Pajno-Ferrara, F., Njai, D. M., and Gaburro, D.: Exocrine pancreas function in premature and full-term neonates. Pediatr. Res., 6: 880 (1972).

84. This research was supported by NIH Grant HD-10823.

85. Received for publication March $1,1978$.

86. Accepted for publication June 1, 1978. 